\title{
Is vein damage the only cause of clinical signs of lower limb chronic venous insufficiency?
}

\author{
É a lesão venosa a única responsável pela clínica da insuficiência \\ venosa crônica dos membros inferiores?
}

Amélia Cristina Seidel', Ricardo Lima Coelho', Mariana Lima Coelho', Cleusa Ema Quillici Belczak²

\begin{abstract}
Background: Venous insufficiency is a very prevalent disease. Some decades ago a group of patients was identified that had symptoms of venous insufficiency, but no visible anatomic abnormalities. Studies showed that this subset had reduced venous tone, and their condition became known as hypotonic phlebopathy. Objective: To investigate prevalence, age group and variations in body mass index (BMI) among patients with hypotonic phlebopathy. Methodology: A total of 1,960 limbs were examined in 1,017 patients who had been referred for complaints compatible with venous insufficiency. Patients with $\mathrm{BMI} \geq 30$ were defined as obese. The patients were examined using color Doppler ultrasonography to detect presence or absence of reflux in veins of the lower limbs and were then distributed into two groups as follows: patients with CEAP $\leq 1$ and no reflux, diagnosed with hypotonic phlebopathy; or patients with CEAP $\geq 2$ and reflux. Results: The study sample comprised $89.7 \%$ women and $10.3 \%$ men with a mean age of 44.9 years. Hypotonic phlebopathy was more common among the women ( $p=0.0001)$. Obese women were more likely than women who were not obese to have venous symptom etiology involving trunk lesions $(p=0.0017)$. Among the men, obesity was unrelated to etiology of symptoms ( $p=0.5991)$. Symptomology was more likely to be related to trunk vein damage among older age groups than among younger age groups ( $p$-valor $<0.0001)$. Conclusions: Hypotonic phlebopathy was very prevalent, particularly among young women who were not obese.
\end{abstract}

Keywords: venous insufficiency; color Doppler ultrasonography; varicose veins.

\begin{abstract}
Resumo
Contexto: A insuficiência venosa é uma doença muito prevalente. Há algumas décadas, evidenciou-se a existência de um grupo que, embora apresentasse sintomas de insuficiência venosa, não possuía alterações anatômicas visíveis. Estudos mostraram redução no tônus venoso nesses indivíduos, denominando-os portadores de flebopatia hipotônica. Objetivo: Estudar a prevalência, a faixa etária e as variações do índice de massa corporal (IMC) em pacientes portadores de flebopatia hipotônica. Metodologia: Foram examinados 1.960 membros de 1.017 pacientes, devido a queixas compatíveis com insuficiência venosa. Foram considerados obesos aqueles com IMC $\geq 30$. Foram avaliados com ecocolor Doppler, para se detectar a presença ou não de refluxo em veias dos membros inferiores, sendo então distribuídos em dois grupos: aqueles com CEAP $\leq 1$, além de excluído refluxo, os portadores de flebopatia hipotônica, e outros com CEAP $\geq 2$ e com refluxo. Resultados: A amostra foi composta por 89,7\% de mulheres e 10,3\% de homens, com faixa etária média de 44,9 anos. A flebopatia hipotônica foi mais comum em mulheres ( $p$-valor = 0,0001). Naquelas obesas, houve mais lesão troncular como etiologia dos sintomas venosos do que nas não obesas ( $p$-valor $=0,0017$ ). Dentre os homens, a presença de obesidade não influenciou na etiologia dos sintomas ( $p$-valor $=0,5991$ ). Nos grupos etários de idade mais avançada, a presença de sintomatologia teve como origem etiológica a lesão venosa troncular com mais frequência do que nas faixas etárias mais jovens ( $p$-valor $<0,0001$ ). Conclusão: A flebopatia hipotônica se mostrou muito prevalente, principalmente em mulheres jovens não obesas.
\end{abstract}

Palavras-chave: insuficiência venosa; ultrassonografia Doppler em cores; veias varicosas.

\footnotetext{
1 Universidade Estadual de Maringá - UEM, Curso de Medicina, Maringá, PR, Brasil.

${ }^{2}$ Faculdade de Ciências Médicas da Santa Casa de São Paulo - FCMSCSP, São Paulo, SP, Brasil.

Financial support: None.

Conflicts of interest: No conflicts of interest declared concerning the publication of this article

Submitted: 08.25.13. Accepted: 01.20.14.
}

The study was carried out at Discipline of Angiology and Vascular Surgery of Curso de Medicina da UEM e Centro Vascular João Belczak. 


\section{INTRODUCTION}

Chronic venous insufficiency (CVI) of the lower limbs (LL) is a common disease, reaching prevalence rates of up to $30 \%$, according to Evans et al., and affecting all ages ${ }^{1,2}$ It is responsible for considerable morbidity, reduces quality of life, causes sufferers to take time off from work and can even be responsible for early retirement. ${ }^{3}$ As a result, CVI places a considerable financial burden on health services. ${ }^{1}$

The principal theory about the etiology and pathophysiology of CVI relates to secondary hypertension caused by reflux in, and/or obstruction of, the venous system and the conditions that lead to these changes are believed to be a combination of genetic predisposition and environmental stimuli. ${ }^{4}$ Other risk factors have also been linked to development of CVI, including age, sex, family history, constipation, obesity, number of gestations and lack of physical activity. ${ }^{5,6}$

Some decades ago, researchers identified a group of patients who were symptomatic, but did not exhibit the anatomic changes characteristic of CVI. Ruckley et al. have demonstrated prevalence rates varying from $3 \%$ to $29 \%$ of the population who exhibit these 'venous' symptoms, but have no sign of varicose veins or telangiectasias. Chiesa et al. report that in approximately $80 \%$ of cases these people have functional legs that are physiologically healthy. Andreozzi et al. have termed this group's condition "hypotonic phlebopathy". ${ }^{7-9}$

Doppler ultrasonography is the most widely used diagnostic method for venous disease because it is an informative, rapid, noninvasive and low cost method. ${ }^{10}$ It is an important method for assessment of LL venous function, both for patients with venous conditions and for asymptomatic people or those with no visible signs of the disease.

Since 'hypotonic phlebopathy' patients are an important group, as shown by the many studies cited above, the objective of this study was to determine prevalence, age and variations in body mass index (BMI) among people seeking medical attention for complaints compatible with CVI, but with no evidence of anatomic damage, in order to improve understanding of the characteristics of these individuals.

\section{MATERIALS AND METHODS}

This was a retrospective study conducted by reviewing the records of 1,017 consultations, relating to a total of 1,960 limbs. Patients had been referred to the Med Imagem ultrasonography laboratory in Maringá, PR, Brazil, with complaints compatible with CVI. The study protocol was approved by the Ethics Committee at our university and permission to consult medical records was granted by the manager of the Clinic.

The study sample was chosen at random and comprised 912 female patients and 105 males, aged from 14 to 86 (mean of 44.9). The predominance of female patients can be explained by sample's origin, i.e., patients referred by private clinics. While the sample is not representative of the entire population with the disease, it is illustrative of the routine at many clinics in this specialty.

Criteria for non-inclusion in the study were deep reflux, arterial insufficiency, diabetes mellitus or prior venous operations.

Data were acquired from records of patient history-taking, physical examinations and Doppler ultrasonography and recorded on a pre-prepared chart. Patients' body mass index (BMI) was calculated and those with $\mathrm{BMI} \geq 30$ were defined as obese, in accordance with the WHO classification.

Doppler examinations were conducted by a vascular surgeon, qualified in Vascular Ultrasonography by the SBACV and the CBR, using a Philips HD $11^{\circledR}$ ultrasound machine with linear transducers from 5 to $7 \mathrm{MHz}$ and convex transducers from 2 to $3 \mathrm{MHz}$ for obese patients, allowing observation of the deep and superficial venous systems and their communicating veins, using techniques described in the literature.

After Doppler ultrasonography, patients were distributed into two groups: I - those with manifest clinical signs of CVI, but no visible anatomic disorders in trunk veins (CEAP classes $\mathrm{C} 0$ and 1 , and with venous reflux excluded by Doppler ultrasonography examination), who were considered to have hypotonic phlebopathy, and II - those with clinical signs of CVI and anatomical damage to trunk veins (CEAP classes 2 to 6 , and with reflux seen on Doppler ultrasonography). These groups were further stratified by sex, BMI and age. Statistical analyses were conducted using GraphPad Prim 5.0 ${ }^{\circledR}$ to apply the chi-square test to detect relationships between signs and symptoms of CVI and presence of anatomic disorders.

\section{RESULTS}

The sample comprised 1,017 patients with clinical signs of CVI in LL, with a total of $1,960 \mathrm{limbs}$ analyzed. This population included 912 women (89.7\%) and 105 men (10.3\%), aged 14 to 86 years (mean of 44.9 years). Patient distribution by age group is given in Table 1, showing that the 30-59 
age bracket had highest prevalence of complaints of CVI, including $70.1 \%$ of the women and $68.57 \%$ of the men analyzed.

A statistical analysis was run to investigate the influence of sex on etiologies and clinical manifestations of CVI, according to the CEAP classification. The results of this analysis are shown in Table 2, demonstrating that $47.5 \%$ of the women had hypotonic phlebopathy, compared with $31.8 \%$ of the men. The difference between these proportions was significant according to the statistical analysis $(p=0.0001)$. It was observed that men complaining of CVI were more likely to have etiology involving anatomic vascular injuries than women.

The following tables demonstrate the influence of obesity on the etiology of venous insufficiency symptomology. These analyses were run separately by sex and the cutoff for obesity was BMI $\geq 30$. Among women who were not obese, $48.9 \%$ were classified as CEAP C0 or C1, and therefore had hypotonic phlebopathy; compared with $37.3 \%$ of obese women. This difference was statistically significant according to the test applied to the

Table 1. Age distribution of sample of patients complaining of venous insufficiency.

\begin{tabular}{ccc}
\hline Age & Female & Male \\
\hline 10-19 years & 8 & 0 \\
20-29 years & 122 & 10 \\
30-39 years & 221 & 21 \\
40-49 years & 243 & 26 \\
50-59 years & 176 & 25 \\
60-69 years & 112 & 14 \\
70-79 years & 26 & 7 \\
80-89 years & 4 & 2 \\
Total & 912 & 105 \\
\hline
\end{tabular}

Table 2. Frequencies of hypotonic phlebopathy patients by sex.

\begin{tabular}{ccc}
\hline CEAP Class & Women & Men \\
\hline 0 and 1 & $837(47.5 \%)$ & $63(31.8 \%)$ \\
2 to 6 & $925(52.5 \%)$ & $135(68.2 \%)$ \\
Total & 1762 & 198 \\
\hline
\end{tabular}

$P=0.0001$

Table 3. Frequencies of obese versus non-obese female hypotonic phlebopathy patients.

\begin{tabular}{ccc}
\hline \multirow{2}{*}{ CEAP Class } & \multicolumn{2}{c}{ Women } \\
\cline { 2 - 3 } & $\mathrm{BMI}<30$ & $\mathrm{BMI} \geq 30$ \\
\hline 0 and 1 & $759(48.9 \%)$ & $78(37.3 \%)$ \\
2 to 6 & $794(51.1 \%)$ & $131(62.7 \%)$ \\
Total & 1553 & 209 \\
\hline
\end{tabular}

$P=0.017$. table $(\mathrm{p}=0.0017)$, demonstrating that obese women had trunk lesions as etiology more often than non-obese women (Table 3 ). Table 4 shows the results of the analysis of the relationship between obesity and CEAP classification for males. Among males, $30.7 \%$ of non-obese patients were classified as having hypotonic phlebopathy, compared with $34.4 \%$ of obese males, which is not a statistically significant difference $(p=0.5991)$, indicating that among the men presence of obesity did not have an influence on etiology of LL symptoms.

Tests were also conducted to detect a possible correlation between age and presence of symptoms (Table 5), subdividing the sample into three age groups. The first group contained patients younger than 30 years old, $64.1 \%$ of whom had hypotonic phlebopathy. The second group covered ages 30-59 years and the third included patients 60 years or older, $45.8 \%$ and $30.8 \%$ of whom had hypotonic phlebopathy, respectively. The differences between these three age groups were statistically significant ( $p$-valor $<0.0001$ ), showing that the etiological origin of symptomology is trunk vein damage more often in older age groups than in younger age groups.

\section{DISCUSSION}

The main symptoms of varicose veins are heaviness, swelling, pain, restless legs, cramps, itching and tingling in the lower limbs. ${ }^{11}$ All of the patients enrolled on this study had clinical signs of CVI, and had been examined by specialists and sent for color Doppler ultrasonography of the venous system.

In this study, there was a high prevalence of women complaining of CVI, which is in line with

Table 4. Frequencies of obese versus non-obese male hypotonic phlebopathy patients.

\begin{tabular}{ccc}
\hline \multirow{2}{*}{ CEAP Class } & \multicolumn{3}{c}{ Men } \\
\cline { 2 - 3 } & $\mathrm{BMI}<30$ & $\mathrm{BMI} \geq 30$ \\
\hline 0 and 1 & $42(30.7 \%)$ & $21(34.4 \%)$ \\
2 to 6 & $95(69.3 \%)$ & $40(65.6 \%)$ \\
Total & 137 & 61 \\
\hline $\mathrm{p}=0.5991$. & &
\end{tabular}

Table 5. Frequencies of hypotonic phlebopathy patients by age.

\begin{tabular}{llll}
\hline \multirow{2}{*}{ CEAP } & \multicolumn{2}{c}{ Age } & \\
\cline { 2 - 4 } & \multicolumn{1}{c}{$<30$ years } & $30-59$ years & \multicolumn{1}{c}{$\geq 60$ years } \\
\hline 0 and 1 & $173(64.1 \%)$ & $631(45.8 \%)$ & $96(30.8 \%)$ \\
2 to 6 & $97(35.9 \%)$ & $747(54.2 \%)$ & $216(69.2 \%)$ \\
Total & 270 & 1378 & 312 \\
\hline
\end{tabular}

$p<0.0001$. 
published data showing that women suffer from vascular diseases with greater frequency than men and are more symptomatic., ${ }^{5,13}$ Jawien found that the most important factors associated with CVI in women were obesity, lack of physical activity and higher numbers of gestations. ${ }^{5}$ We could infer from this that males do not consider phlebostatic symptoms to be important, in contrast with women, who do, and therefore seek medical attention for this type of symptoms. ${ }^{9}$

The age group most affected in this sample was $30-59$ years, which is similar to the result of another study, ${ }^{6}$ in which the age group most affected by CVI was from 45 to 64 years. Other studies have shown that the incidence of CVI increases with age, particularly in terms of the emergence of signs of increasing severity, which is in line with our finding that the greater the age of the patient the more likely it is that their CVI symptoms are related to anatomic disorders. ${ }^{8,14}$

Using the CEAP classification, considered the gold standard for classification of chronic venous diseases, ${ }^{3}$ telangiectasias are not considered to be varicose veins.

Doppler ultrasonography is used to precisely determine the presence or absence of venous reflux, ${ }^{15}$ since it is known that some patients may have venous insufficiency even when there are no visible signs of the disease. ${ }^{16}$ Doppler examinations were conducted using a technique described in the literature. ${ }^{17}$

This study was designed to investigate a group of individuals with a high prevalence in the population: cases in which there are clinical signs of CVI, but etiology is not vascular disease, in other words, there are no varicose veins. During the 1970s, Bassi coined the term 'functional phlebopathy' to describe this group that exhibits insufficient vascular function in the absence of anatomic abnormalities. ${ }^{18}$ The prevalence of this subset has varied from $3 \%$ to $29 \%$ of the population in previous studies. ${ }^{7,9}$

The results of several investigations show that the habitual anatomic disorders expected in CVI, such as obstructed flow and/or reflux, are not sufficient to explain the symptoms exhibited by this subset of patients..$^{9,19}$

A study conducted by Acireale showed that patients with symptoms of CVI, but no varicose veins have increased vessel wall complacency. Additionally, this subset of patients exhibited significant improvements when given phlebotonic drugs. Since the pathophysiological basis of varicose symptoms without varicose veins is reduced venous tone and increased complacency of the vessel wall,
Andreozzi et al. proposed that the condition be called 'hypotonic phlebopathy. ${ }^{9}$ On this basis, we used this term to describe the subset of patients in our sample who were symptomatic but did not have varicose veins $(\mathrm{C} 0$ and $\mathrm{C} 1)$ or venous reflux.

Other hypotheses have also been raised to attempt to explain the etiology of symptomology in these patients with no venous reflux. One hypothesis is that these patients have microangiopathic disorders that cannot be detected using Doppler ultrasonography. It is known that patients with CVI exhibit abnormalities of microcirculation, such as fewer capillaries and changes in capillary morphology, reduced oxygen concentration in the skin and greater capillary permeability to low molecular weight substances. ${ }^{20}$ Another alternative hypothesis is that macrovascular changes are intermittent and are only present at the end of the day or at different points during the menstrual cycle. ${ }^{21}$

Andreozzi et al. studied of a group of these individuals using photoplethysmography and found that they had reduced calf muscle pump efficacy, suggesting that their symptoms may be caused by a reduction in the tone of vein walls, ${ }^{22}$ since plethysmography parameters normalized when venous tone was increased artificially using elastic compression stockings, which are known to potentiate calf muscle pump (BMP) function. ${ }^{23}$

The statistically significant difference between sexes in terms of whether or not etiology was related to anatomic vascular injury is in line with the results of other studies, such as the one published by Andreozzi et al. and another by Chiesa et al., both of which found double the prevalence of hypotonic phlebopathy among women, irrespective of age group. ${ }^{8,9}$

The influence of obesity as an etiologic component of venous disease symptomology was also investigated, using the World Health Organization (WHO) definition of obesity as BMI $\geq 30 \mathrm{~kg} / \mathrm{m}^{2}$.

There is considerable divergence in the literature on the subject of whether or not obesity is considered a risk factor for CVI. There are studies that claim that there is only a relationship between obesity and $\mathrm{CVI},{ }^{3,6,24}$ or an association between varicose veins and BMI, among women, ${ }^{1,5,14,25}$ and others that found no evidence of any relationship. ${ }^{14,26}$ It does not appear likely that obesity could be a risk factor for one sex but not for the other, and it can be considered as an aggravating factor in venous disease. ${ }^{18,25,27}$

In this study, obese women were more likely to have trunk lesions as etiology of their symptoms. Hypotonic phlebopathy, defined as CVI 
symptomology in the absence of varicose veins, was more common among women who were not obese. Among the men, obesity did not affect symptom etiology and so hypotonic phlebopathy was unrelated to obesity. This result contrasts with data reported by Andreozzi et al., ${ }^{9}$ since they found a relationship between hypotonic phlebopathy and obesity, but it is in line with other results in the literature indicating that the association between BMI and varicose veins is stronger among women. . $^{1,5,14,25}$

Another factor investigated was distribution by age group of the hypotonic phlebopathy patients. This analysis showed that the highest prevalence $(64 \%)$ is among younger people aged $<30$ years (2:1) and that prevalence reduces as age increases, as symptoms become more likely to be related to anatomic venous injuries. This finding may be linked to the fact that this is the age group in which people are engaged in their employment at greatest intensity. Many studies have shown that age is a risk factor for varicose veins and for exacerbation of CVI. ${ }^{8,14,25}$ The Acireale project described by Andreozzi et al. found that the prevalence of this subset was $15 \%$. The difference can be explained by the fact that the sample described in the present article was made up of symptomatic patients, whereas Andreozzi et al. calculated the prevalence in a sample representative of the general population. ${ }^{9}$

Sugerman et al. studied patients with class III obesity and symptoms of CVI, finding that two thirds of the limbs examined did not exhibit evidence of anatomic venous disease. ${ }^{24}$ In another study, approximately $30 \%$ of patients with symptoms of varicose veins who were examined did not have reflux. ${ }^{26}$ It can be inferred that obese people are generally sedentary and despite the large circumference of their legs, due to fat, they have undeveloped calf muscles, which undoubtedly reduces the volume ejected, increasing venous stasis and leading to symptomology.

In a future investigation, it would be of interest to measure the calf ejection fraction in patients with symptoms but no anatomic damage using air plethysmography, in order to identify and measure any BMP dysfunction that could be the origin of the clinical presentation observed. It is known that in modern life many jobs, such as computer-based work, working at checkouts, performing manicures etc., involve remaining in a static position for 8 hours or more per day, which promotes lethargic venous flow. These types of activities, combined with the inactivity that many people exhibit, could cause hypotonic phlebopathy through muscle inactivity, which is a phenomenon primarily seen in tall and thin people with undeveloped calves.

\section{CONCLUSIONS}

It can be concluded that the prevalence of hypotonic phlebopathy is significant, particularly among young women who are not obese. The sample described in this article was limited to patients who had been referred to a vascular ultrasonography center and so the results cannot be generalized to entire populations. Notwithstanding, these results do demonstrate that patients with hypotonic phlebopathy comprise a very prevalent subset of the patients who seek medical attention for symptoms considered to be venous.

\section{REFERENCES}

1. Evans CJ, Fowkes FGR, Ruckley CV, Lee AJ. Prevalence of varicose vein and chronic venous insufficiency in men and women in the general population: Edinburg Vein Study. J Epidemiol Community Health. 1999;53:149-53. PMid:10396491 PMCid:PMC1756838. http://dx.doi.org/10.1136/jech.53.3.149

2. Slagsvold CE, Stranden E, Rosales A. Venous insufficiency in the lower limbs. Tidsskr Nor Laegeforen. 2009;129:2256-9. PMid:19898578. http://dx.doi.org/10.4045/tidsskr.09.0238

3. Pannier F, Rabe E. The relevance of the natural history of varicose veins and refunded care. Phlebology. 2012;27:23-6. PMid:22312063. http://dx.doi.org/10.1258/phleb.2012.012S23

4. Pappas PJ, Lal BK, Cerveira JJ, Padberg FT Jr, Duran WN. Causes of severe chronic venous insufficiency. Semin Vasc Surg. 2005;18:30-5. PMid:15791551. http://dx.doi.org/10.1053/j. semvascsurg.2004.12.009

5. Jawien A. The influence of environmental factors in chronic venous insufficiency. Angiology. 2003;54:S19-S31. PMid:12934754. http://dx.doi.org/10.1177/000331970305400104

6. Dimakakos E, Syrigos K, Scliros E, Karaitianos I. Prevalence, risk and aggravating factors of chronic venous disease: an epidemiological survey of the general population of Greece. Phlebology. 2013;28:184-90. PMid:22451459.

7. Ruckley CV, Evans CJ, Allan PL, Lee AJ, Fowkes FG. Telangiectasia in the Edinburgh Vein Study: epidemiology and association with trunk varices and symptoms. Eur J Vasc Endovasc Surg. 2008;36:719-24. PMid:18848475. http://dx.doi.org/10.1016/j. ejvs.2008.08.012

8. Chiesa R, Marone EM, Limoni C, Volonte M, Petrini O. Chronic venous disorders: correlation between visible signs, symptoms, and presence of functional disease. J Vasc Surg. 2007;46:322-30. PMid:17600668. http://dx.doi.org/10.1016/j.jvs.2007.04.030

9. Andreozzi GM, Signorelli S, Di Pino L, et al. Varicose symptoms without varicose veins: the hypotonic phlebopathy, epidemiology and pathophysiology. The Acireale project. Minerva Cardioangiol. 2000;48:277-85.

10. Labropoulos N, Leon LR Jr. Duplex evaluation of venous insufficiency. Semin Vasc Surg. 2005;18:5-9. http://dx.doi. org/10.1053/j.semvascsurg.2004.12.002

11. Bradbury A, Evans C, Allan P, Lee A, Ruckley CV, Fowkes FG. What are the symptoms of varicose veins? Edinburgh vein study cross sectional population survey. BMJ. 1999;318:353-56. PMid:9933194 PMCid:PMC27720. http://dx.doi.org/10.1136/bmj.318.7180.353 
12. Fowkes FGR, Evans CJ, Lee AJ. Prevalence and risk factors of chronic venous insufficiency. Angiology. 2001;52:S5-S15. PMid:11510598. http://dx.doi.org/10.1177/000331970105200102

13. Beebe-Dimmer JL, Pfeifer JR, Engle JS, Schottenfeld D. The epidemiology of chronic venous insufficiency and varicose veins. Ann Epidemiol. 2005;15:175-84. PMid:15723761. http://dx.doi. org/10.1016/j.annepidem.2004.05.015

14. Benigni JP, Cazaubon M, Tourneroche A, Achhammer I, Mathieu $M$. Is obesity an aggravating factor in chronic venous disease? Results of a French epidemiological study in male patients. Int Angiol. 2006;25:297-303. PMid:16878080.

15. Labropoulos N, Touloupakis E, Giannoukas AD, Leon M, Katsamouris A, Nicolaides AN. Recurrent varicose veins: investigation of the pattern and extent of reflux with color flow duplex scanning. Surgery. 1996;119:406-9. http://dx.doi. org/10.1016/S0039-6060(96)80140-1

16. Safar H, Shawa N, Al-Ali J, Al-Nassar M, Dashti H, Asfar S. Is there a need for Doppler vascular examination for the diagnosis of varicose vein? A prospective study. Med Princ Pract. 2004;13:43-6. PMid:14657619. http://dx.doi.org/10.1159/000074051

17. van Bemmelen PS, Bedford G, Beach K, Strandness DE. Quantitative segmental evaluation of venous valvular reflux with duplex ultrasound scanning. J Vasc Surg. 1989;10:425-31. http:// dx.doi.org/10.1016/0741-5214(89)90417-5

18. Bassi G. La patologia venosa funzionale. In: Bassi G, editor. Compendio di terapia flebologica. Torino: Minerva Medica Ed, 1985.

19. Padberg F Jr, Cerveira JJ, Lal BK, Pappas PJ, Varma S, Hobson RW 2nd. Does severe venous insufficiency have a different etiology in the morbidly obese? Is it venous? J Vasc Surg. 2003;37:79-85. PMid:12514581. http://dx.doi.org/10.1067/mva.2003.61

20. Junger $M$, Steins $A$, Hahn $M$, Hafner HM. Microcirculatory dysfunction in chronic venous insufficiency (CVI). Microcirculation. 2000;7:S3-12. PMid:11151969. http://dx.doi. org/10.1080/713774003

21. Bradbury A, Evans CJ, Allan P, Lee AJ, Ruckley CV, Fowkes FG. The relationship between lower limb symptoms and superficial and deep venous reflux on duplex ultrasonography: The Edinburgh Vein Study. J Vasc Surg. 2000;32:921-31. PMid:11054224. http:// dx.doi.org/10.1067/mva.2000.110509

22. Monaco S, Ferrara M, Minardo G, Minacapelli C, Signorelli $S$, Andreozzi GM. La reografia a luce riflessa (RLR) nella valutazione della flebopatia ipotonica costituzionale. Acta Cardiol Medit. 1986;4:155- 60

23. Ferrara M, Monaco S, Cacciaguerra G, et al. Pressioni Venose e Tono Parietale Venoso. Acta Cardiol Medit. 1986;4:177-83.
24. Sugerman HJ, Sugerman EL, Wolfe L, Kellum JM Jr, Schweitzer MA, DeMaria EJ. Risks and benefits of gastric bypass in morbidly obese patients with severe venous stasis disease. Ann Surg. 2001;234:41-6. PMid:11460821 PMCid:PMC1421946. http:// dx.doi.org/10.1097/00000658-200107000-00007

25. Robertson L, Evans C, Fowkes FG. Epidemiology of chronic venous disease. Phlebology. 2008;23:103-11. PMid:18467617. http:// dx.doi.org/10.1258/phleb.2007.007061

26. Seidel AC, Mangolim AS, Rossetti LP, Gomes JR, Miranda $F$ Jr. Prevalência de insuficiência venosa superficial dos membros inferiores em pacientes obesos e não obesos. J Vasc Bras. 2011;10:124-30. http://dx.doi.org/10.1590/ S1677-54492011000200006

27. Kostas TI, loannou CV, Drygiannakis I, et al. Chronic venous disease progression and modification of predisposing factors. J Vasc Surg. 2010;51:900-7. PMid:20347686. http://dx.doi. org/10.1016/j.jvs.2009.10.119

Correspondence Amélia Cristina Seide Rua Dr. Gerardo Braga, 118 - Jardim Vila Rica CEP 87050-610 - Maringá (PR), Brasil Fone: +55 (44) 3026-7590 Fax: +55 (44) 3025-4242 E-mail: seidel@wnet.com.br

Author information ACS is an Associate Professor of Angiology and Vascular Surgery, School of Medicine, Universidade Estadual de Maringá (UEM) and a Vascular Ultrasonographist from SBACV and CBR. RLC and MLC are Medical Students at Universidade Estadual de Maringá (UEM)

CEQB is a PhD in General Surgery from the School of Medical Sciences at Santa Casa de São Paulo (FCMSCSP).

Author contributions Conception and design: ACS, CEQB Analysis and interpretation: RLC Data collection: ACS, MLC, RLC Writing the article: MLC, RLC Critical revision of the article: $A C S, C E Q B$ Final approval of the article*: ACS, CEQB, MLC, RLC Statistical analysis: RLC Overall responsibility: ACS

${ }^{*}$ All authors have read and approved of the final version of the article submitted to J Vasc Bras. 